\title{
Interleukin-1B gene in esophageal, gastric and colorectal carcinomas
}

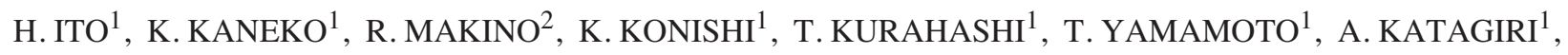 \\ Y.KUMEKAWA ${ }^{1}$, Y.KUBOTA ${ }^{1}$, T. MURAMOTO ${ }^{1}$, K. MITAMURA $^{1}$ and M. IMAWARI ${ }^{1}$ \\ ${ }^{1}$ Second Department of Internal Medicine and ${ }^{2}$ Clinical Research Laboratory, \\ Showa University School of Medicine, Tokyo 142-0064, Japan
}

Received March 7, 2007; Accepted April 9, 2007

\begin{abstract}
Interleukin (IL)-1 gene polymorphisms are associated with development of gastric atrophy and with increased risk of gastric carcinoma. A - $31 \mathrm{C}$ to $\mathrm{T}$ base transition in the promoter region of this gene is involved in carcinogenic changes within the stomach, especially in Helicobacter pylori infected individuals. We examined association between IL-1 locus polymorphisms and risk of esophageal, gastric and colorectal carcinomas in Japanese patients with $H$. pylori infection. IL-1B and IL-1RN polymorphisms were analyzed in 136 controls, 75 patients with esophageal carcinoma, 186 patients with gastric carcinoma, 69 patients with colorectal carcinoma, and 18 patients with ulcerative colitis (UC). For IL-1B-511 and -31 polymorphisms were determined by fluorescence-based polymerase chain reaction single-strand conformation polymorphism analysis. For IL-1 receptor antagonist gene (IL-1RN), penta-allelic variable number of tandem repeats (VNTR) was determined by PCR-standard agarose gel electrophoresis. For gastric carcinoma, IL-1B-511 heterozygotes (OR, 0.48; 95\% CI, 0.3-0.9; $\mathrm{p}=0.0115)$ and $\mathrm{T}$ carriers (OR, 0.52; 95\% CI, 0.3-1.0; p=0.0185) had a significantly reduced risk of carcinoma. For colorectal carcinoma, IL-1B-511 heterozygotes (OR, 0.34; 95\% CI, $0.2-0.7 ; \mathrm{p}=0.0028)$ and $\mathrm{T}$ carriers (OR, 0.43; 95\% CI, 0.2$0.9 ; \mathrm{p}=0.0015$ ) had a significantly low risk of carcinoma. No significant difference was observed in the frequencies of IL-1B-31C/T and IL-1RN genotypes between controls and the esophageal carcinoma patients. Our results shows that IL-1B-511C/T and $\mathrm{T}$ carrier state may indicate less risk for gastric and colorectal carcinoma in the Japanese population.
\end{abstract}

Correspondence to: Dr Kazuhiro Kaneko, Second Department of Internal Medicine, Showa University School of Medicine, 1-5-8 Hatanodai, Shinagawa-ku, Tokyo 142-0064, Japan

E-mail:gikaneko@med.showa-u.ac.jp

Key words: esophageal carcinoma, gastric carcinoma, colorectal carcinoma, interleukin-1ß, Helicobacter pylori, polymorphism

\section{Introduction}

Gastric carcinoma remains the second most common carcinoma, having been superceded only by lung carcinoma in the late 1980s on a global scale (1). Gastric carcinoma shows substantial international variation in incidence, with the highest rates reported in Japan and eastern Asia. Other high incidence areas include Eastern Europe and parts of Latin America, whereas Western Europe and the United States generally have low incidence rates (1). Discovery of Helicobacter pylori (H.pylori) in the early 1980 s has proved a turning point in understanding the pathogenesis of this carcinoma. H. pylori infection, a well-known risk factor for gastric carcinoma, depends largely on sanitary conditions, especially in childhood (2-4). Substantial differences persist in the prevalence of childhood infection between developed and developing countries, ranging from 4 to $82 \%$ (3). Although exposure to the bacterium is an important determinant of infection rate in a population, host susceptibility also is an important factor. The H. pylori infection rate in Japan is higher than in other populations, especially those in Western countries (5-7). According to previous reports, $60-70 \%$ of the populations over 60 years of age in Japan are infected with $H$. pylori, this rate is close to the $H$. pylori positivity rate of gastric carcinoma cases in Japan (5-7). Epidemiological studies have identified risk factors for gastric carcinoma include sex, $H$. pylori infection, high salt intake, low ascorbic acid intake, exposure to exogenous or endogenously induced nitroso compounds, and gastric musosal changes representing a precancer to cancer sequence (8-10).

Recently, genetic polymorphisms of interleukin (IL)-1, which is a 100 -fold more potent inhibitor of gastric secretion than proton-pump inhibitors, have been linked to physiologic differences between individuals in the effect of IL-1 on gastric secretion (11). IL-1 is a potent proinflammatory cytokine (12) that is upregulated in the presence of $H$. pylori and is important in initiating and amplifying the inflammatory response to this infection $(13,14)$. The IL-1 receptor antagonist (IL-1ra) is a naturally occurring anti-inflammatory cytokine that binds competitively to IL-1 receptors, thus blunting potentially injurious effects of IL-1 (15). Polymorphisms of IL-1B and IL-1RN (encoding IL-1 ra) were reported to be associated with gastric carcinoma risk in a Polish population (16). 
Table I. Characteristics of controls and carcinoma cases.

\begin{tabular}{|c|c|c|c|c|c|}
\hline & \multirow[b]{2}{*}{$\begin{array}{c}\text { Control } \\
\text { subjects }(\%)\end{array}$} & \multicolumn{4}{|c|}{ Patients with } \\
\hline & & $\begin{array}{c}\text { Esophageal } \\
\text { carcinoma }(\%)\end{array}$ & $\begin{array}{c}\text { Gastric } \\
\text { carcinoma }(\%)\end{array}$ & $\begin{array}{c}\text { Colorectal } \\
\text { carcinoma (\%) }\end{array}$ & $\mathrm{UC}(\%)$ \\
\hline No. & 136 & 75 & 186 & 69 & 18 \\
\hline Age year (range) & $60(35-80)$ & $68(55-82)$ & $67(49-88)$ & $70(55-84)$ & $42(28-65)$ \\
\hline \multicolumn{6}{|l|}{ Gender } \\
\hline Males & $95(70)$ & $60(80)$ & $130(70)$ & $41(59)$ & $9(50)$ \\
\hline Females & $41(30)$ & $15(20)$ & $56(30)$ & $28(41)$ & $9(50)$ \\
\hline \multicolumn{6}{|l|}{ Drinking habits } \\
\hline Non-drinkers & $80(59)$ & $11(15)$ & $117(63)$ & $39(57)$ & $16(89)$ \\
\hline Drinkers & $56(41)$ & $64(85)$ & $69(37)$ & $30(43)$ & $2(11)$ \\
\hline $\begin{array}{l}\text { Mean alcohol intake } \\
(\mathrm{g}) / \text { day }\end{array}$ & 15 & 63 & 17 & 17 & 12 \\
\hline $\begin{array}{l}\text { Mean total amount } \\
\text { of alcohol }(\mathrm{kg})\end{array}$ & 160 & 715 & 230 & 221 & 80 \\
\hline \multicolumn{6}{|l|}{ Smoking habits } \\
\hline Non-smokers & $94(69)$ & $11(15)$ & $114(61)$ & $42(61)$ & $14(78)$ \\
\hline Smokers & $42(31)$ & $64(85)$ & $72(39)$ & $27(39)$ & $4(22)$ \\
\hline \multicolumn{6}{|l|}{ Brinkman index } \\
\hline 0 & $94(69)$ & $11(15)$ & $114(61)$ & $42(61)$ & $14(78)$ \\
\hline 0 to $\leq 400$ & $20(15)$ & 7 (9) & $18(10)$ & $6(9)$ & $3(17)$ \\
\hline$<400$ & $22(16)$ & $57(76)$ & $54(29)$ & $21(30)$ & $1(5)$ \\
\hline
\end{tabular}

No., number of patients; UC, ulcerative colitis.

IL-1B has three diallelic polymorphisms located at -511 , -31 and +3954 base pairs (bp) from the transcriptional start site. Although the differences were not statistically significant, persistent $H$. pylori infection was observed in $60 \%$ of individuals harboring the $\mathrm{C} / \mathrm{C}$ genotype $(\mathrm{n}=58)$ at -31 of IL-1B, in $73 \%$ of those with the $\mathrm{C} / \mathrm{T}$ genotype $(\mathrm{n}=67)$, and in $79 \%$ of those with the T/T genotype $(n=24)$ in a Scottish population study (16). The $\mathrm{T}$ allele at -31 forms a TATA box that is suspected of enhancing gene expression. The study reported that the polymorphism at -511 was linked tightly with the polymorphism at -31 . Accordingly, quite similar findings on the risks of gastric carcinoma and $H$. pylori infection were obtained for IL-1BC-511T. IL-1RN has a penta-allelic 86-bp tandem repeat polymorphism in intron 2 , which was found to affect IL-1 production in vitro (17) but not to be associated with $H$. pylori infection (16).

While El-Omar et al studied a Polish population (16), we investigated a Japanese population. We aimed to determine whether the putative association between IL-1 loci polymorphisms and risk of carcinoma varies according to the specific gastrointestinal organ (esophagus, stomach and large intestine).

\section{Materials and methods}

Patients. The study included 466 untreated Japanese patients, with no hereditary predisposition of carcinoma, who consulted our hospital in Tokyo between 1994 and 2002. The control subjects were selected from patients visiting at our hospital, and these subjects were consecutive patients attending for routine endoscopy. Thus, no asymptomatic healthy volunteer was included in this study. There was no subject having past history of any carcinoma or peptic ulcer. The subjects without $H$. pylori infection were excluded from our study. Groups of subjects included a control group $(n=136)$ and patients with esophageal carcinoma $(n=75)$, gastric carcinoma $(n=186)$, colorectal carcinoma $(n=69)$, and ulcerative colitis (UC) $(n=18)$ (Table I). The patients with colorectal carcinoma had no past history of UC. In the control group, the average age was 66 years (range, 32-82) and the male:female ratio was $7: 3$. In the esophageal carcinoma group, they were 68 years (55-82) and 8:2; in the gastric carcinoma group, 67 years (49-88) and 7:3; in the colorectal carcinoma group, 70 years (55-84) and 6:4; and in the UC group, 42 years (28-65) and $5: 5$. No significant differences in the mean age and gender 
ratio were noted between the control subjects and patients with esophageal carcinoma, gastric carcinoma or colorectal carcinoma.

Assessment of H. pylori status in carcinoma patients and controls. Control subjects and all patients with esophageal, gastric, colorectal carcinoma cases, and UC cases confirmed $H$. pylori infection by the use of ${ }^{14} \mathrm{C}$-urea breath test (18), culture, and histopathological examination. Both culture and histopathological examination were performed in all 466 subjects at the time of endoscopy. Specimens of tissue for culture were obtained from corpus of stomach, and those for histopathological examination were obtained from both corpus and antrum. ${ }^{14} \mathrm{C}$-urea breath test was performed in $\sim 40 \%$ of all subjects within a few days before or after endoscopic examination. $H$. pylori infection was considered positive if results of at least one among the three tests were positive. During endoscopic examination, biopsy specimens were obtained from the antral region within $2 \mathrm{~cm}$ of the pyloric ring and from the body region of the stomach between 50 and $55 \mathrm{~cm}$ along the greater curvature. H. pylori infection was defined to be negative if the results of all three tests were negative, and these patients were excluded from the study. The degree of inflammation and atrophy in the corpus and antrum were assessed according to the updated Sydney system (19), since patients with extensive corpus gastritis develop hypochlorhydria and gastric atrophy, which are presumptive precursors of gastric carcinoma $(8,20)$.

Record of daily consumption of alcohol and/or cigarettes. Daily amount (g) and periods (years) of alcohol intake were recorded in individual patients and control subjects. The amount of alcohol drinking was exchanged into weight (g/day and $\mathrm{kg} /$ total) of $100 \%$ ethanol. Daily number and periods of cigarette smoking were also recorded. Frequencies of alcohol intake and cigarette smoking in the esophageal carcinoma, gastric carcinoma, and colorectal carcinoma groups were compared with those in the controls. Daily amount of alcohol or cigarettes, total amount of alcohol intake and Brinkman index (B.I.) in the esophageal carcinoma, gastric carcinoma, and colorectal carcinoma groups were compared with those in the controls.

Tissue processing. Diagnosis of carcinoma was confirmed histopathologically in biopsy specimens using hematoxylin and eosin staining. Genomic DNA from the control and carcinoma groups (esophagus, stomach and large intestine), and UC group were isolated from frozen samples of nonneoplastic mucosa by standard proteinase K-phenol/chloroform extraction methods (21), after obtaining the patients informed consent. The study protocol was approved by the Human Ethics Review Committee of the Showa University School of Medicine. All non-neoplastic tissues were confirmed histologically to contain normal mucosa.

Genotyping of $I L-1 B-31,-511$ and IL-1RN VNTR. We evaluated the IL-1B-31, -511 biallelic and IL-1RN pentaallelic variable number of tandem repeats (VNTR) polymorphisms. The IL-1B-31, $-511 \mathrm{C} / \mathrm{T}$ biallelic polymorphism was genotyped by fluorescence-based polymerase chain reaction single-strand conformation polymorphism (PCP-

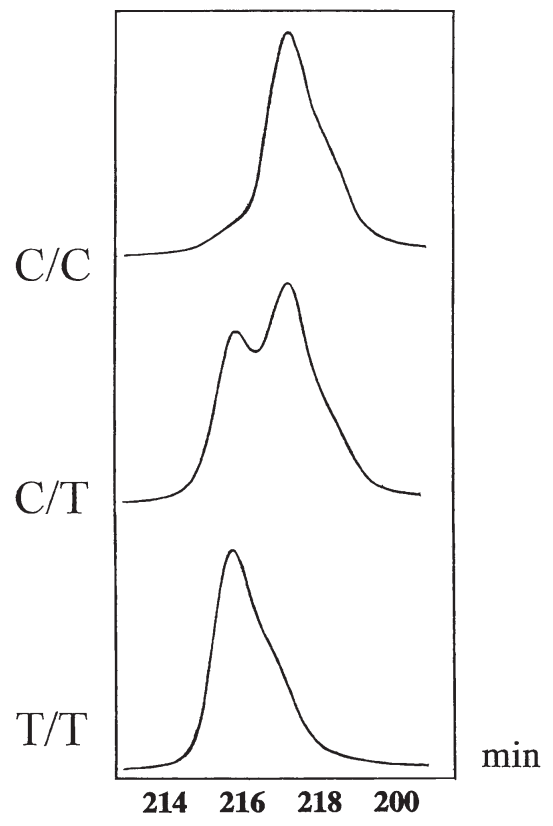

Figure 1. Genotyping of the IL-1B-31C/T: PCR-SSCP analysis of the IL-1B$31 \mathrm{C} / \mathrm{T}$ polymorphism showing the $\mathrm{C} / \mathrm{C}, \mathrm{T} / \mathrm{T}, \mathrm{C} / \mathrm{T}$ genotypes.

SSCP) analysis $(21,22)$ and the IL-1RN penta-allelic VNTR by PCR-standard agarose gel electrophoresis. Primers used for PCR were based on those reported by El-Omer et al (16). The PCR reaction mixtures were carried out in a $20-\mu 1$ final volume, containing 0.5 units of Takara ExTaq (Takara, Shiga, Japan), $1 \mu \mathrm{mol}$ of each primer, $2.5 \mathrm{mM}$ of each deoxyribonucleoside triphosphatase, and $10 \times$ ExTaq buffer containing $100 \mathrm{mM}$ Tris- $\mathrm{HCl} \mathrm{pH} 8.3,500 \mathrm{mM} \mathrm{KCl}, 15 \mathrm{mM} \mathrm{MgCl}_{2}$ (Takara). For amplification of DNA fragments in frozen tissue, $50 \mathrm{ng}$ of DNA was subjected to 30 cycles of $94^{\circ} \mathrm{C}$ for $30 \mathrm{sec}$, $55^{\circ} \mathrm{C}$ for $30 \mathrm{sec}$ and $72^{\circ} \mathrm{C}$ for $1 \mathrm{~min}$. To purify and visualize PCR products, the PCR products were electrophoresed on $2 \%$ agarose gels, and stained with ethidium bromide. SSCP was performed using an ALFexpress automated DNA seqencer (Amersham Pharmacia Biotech, Uppsala, Sweden) with a temperature-controlled cooling waterbath. Peak patterns were analyzed using the ALFwin Fragment Analyser program (Amersham Pharmacia Biotech). Samples showing peak sifts were considered polymorphic (Fig. 1). Nucleotide sequences of fragments showing peak shifts were determined using the ABI PRISM ${ }^{\circledR}$ BigDye $^{\text {TM }}$ Terminator Cycle Sequencing Kit (Applied Biosystems, CA), using an ABI PRISM ${ }^{\circledR} 310$ Genetic Analyzer (Applied Biosystems).

The IL-1RN gene has a penta-allelic 86-base pair tandem repeat in the second intron (23), and the alleles were coded conventionally as follows: allele 1,4 repeats; allele 2, 2 repeats; allele 3, 5 repeats; allele 4, 3 repeats; and allele 5, 6 repeats (Fig. 2). Given the rarity of alleles 3, 4 and 5, this polymorphism was treated as biallelic for statistical analysis by dividing alleles into short and long categories, with a short allele having two repeats (allele 2) and a long allele having three or more repeats (alleles 1,3,4 and 5).

Statistical analysis. Differences in genotype frequencies between cases and controls were assessed by chi-square test. Student's-t test, odds ratios (ORs) with $95 \%$ confidence 


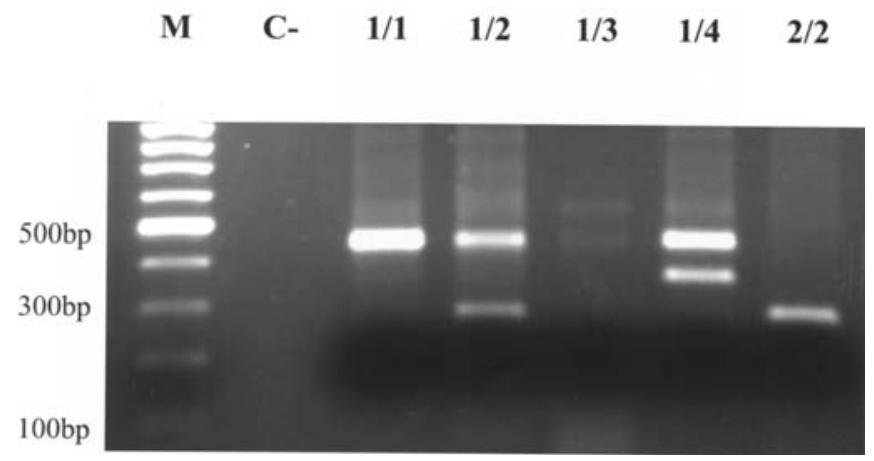

Figure 2. PCR/agarose gel electrophoresis of the IL-1RN VNTR polymorphism (M, size marker; C-, negative control).

intervals (CIs) and unconditional logistic regression models were computed using the SPSS software program (SPSS Science, Chicago, IL). Haplotype frequencies for pairs of alleles were estimated and Linkage disequibrium coefficients $D^{\prime}=D / D_{\max }$ and $\chi^{2}$ values were calculated using the SNPAlyze (Dynacom Co., Ltd.). P-values $<0.05$ were considered significant.

\section{Results}

Estimated haplotype frequencies and linkage disequilibrium coefficients. Table II shows estimated haplotype frequencies and linkage disequilibrium coefficients of the IL-1B and IL-1RN. There was marked strong linkage disequilibrium ( $\left.D^{\prime} \sim 0.5, \mathrm{P}=0.0001\right)$ between IL-1B-31 and IL-1B-511 in the patients and the control subjects. Also there was strong linkage disequilibrium between IL-1B-31 and IL-1RN in patients with esophageal carcinoma and colorectal carcinoma.

Genotype frequencies in control cases. Tables III and IV list the genotype frequencies in control cases. A near-complete linkage disequilibrium was observed between polymorphisms at -31 and -511 of IL-1B; $22.8 \%(31 / 136)$ for $\mathrm{C} / \mathrm{C}$ at -31 and $\mathrm{T} / \mathrm{T}$ at $-511,58.8 \%(80 / 136)$ for $\mathrm{C} / \mathrm{T}$ and $\mathrm{C} / \mathrm{T}, 17.6 \%$ (24/ 136) for $\mathrm{T} / \mathrm{T}$ and $\mathrm{C} / \mathrm{C}, 0.7 \%$ (1/136) for $\mathrm{T} / \mathrm{T}$ and $\mathrm{T} / \mathrm{T}$, and none for the other combinations. Participants harboring the $1 / 1$ genotype of IL-1RN represented $93 \%$ of the total.

$I L-1 B-31 C / T$. In patients with esophageal carcinoma, there was no significant difference in genotype frequency between patients and the control subjects $\left(\chi^{2}=0.691, p=0.708\right.$, Table III). Genotype frequencies in patients with esophageal carcinoma were similar to control subjects and genotypic specific risks were not high. A significant difference in genotype frequency was observed between patients with gastric carcinoma and control subjects $\left(\chi^{2}=6.437, p=0.040\right)$. A modest increase in risk of gastric carcinoma was observed for IL-1B-31T homozygotes, but this was not statistically significant (OR, $1.52 ; 95 \% \mathrm{CI}, 0.8-2.9 ; \mathrm{p}=0.214)$. Comparison of genotype frequencies showed a significant difference between patients with colorectal carcinoma and control subjects $\left(\chi^{2}=9.033\right.$, $\mathrm{p}=0.011)$. A modest increase in risk of colorectal carcinoma was observed for IL-1B-31T homozygotes, but this was not statistically significant (OR, 1.43; 95\% CI, 0.6-3.1; $\mathrm{p}=0.383)$. Genotype frequencies in patients with UC were similar to control subjects $\left(\chi^{2}=0.042, p=0.979\right)$ and genotypic specific risks were not high (Table III).

Table II. Estimated haplotype frequencies and linkage disequilibrium coefficients.

\begin{tabular}{|c|c|c|c|c|c|c|c|c|c|c|}
\hline \multirow[b]{2}{*}{ Population } & \multirow[b]{2}{*}{ Loci } & \multicolumn{6}{|c|}{ Haplotype $^{\text {a }}$} & \multicolumn{3}{|c|}{ Disequilibrium } \\
\hline & & $1-1$ & $1-2$ & $2-1$ & $2-2$ & $1-3,4,5$ & $1-3,4,5$ & $D^{\prime}$ & $X 2$ & $\mathrm{P}$ \\
\hline \multirow[t]{3}{*}{ Control } & IL-1B-31/1B-511 & 0.011 & 0.467 & 0.518 & 0.004 & & & -0.98 & 256.3 & 0.0001 \\
\hline & IL-1B-31/1RN & 0.505 & 0.009 & 0.455 & 0.024 & 0.007 & & 0.21 & 3.124 & 0.2097 \\
\hline & IL-1B-511/1RN & 0.446 & 0.024 & 0.513 & 0.009 & 0.001 & 0.007 & 0.24 & 3.177 & 0.2042 \\
\hline \multicolumn{11}{|c|}{ Esophageal carcinoma } \\
\hline & IL-1B-31/1B-511 & 0.014 & 0.433 & 0.526 & 0.027 & & & -0.94 & 126.9 & 0.0001 \\
\hline & IL-1B-31/1RN & 0.513 & 0.040 & 0.433 & 0.001 & 0.001 & 0.012 & 0.47 & 7.391 & 0.0248 \\
\hline & IL-1B-511/1RN & 0.430 & 0.016 & 0.516 & 0.024 & 0.013 & 0.001 & 0.19 & 2.738 & 0.2543 \\
\hline \multicolumn{11}{|c|}{ Gastric carcinoma } \\
\hline & IL-1B-31/1B-511 & 0.008 & 0.519 & 0.468 & 0.005 & & & -0.97 & 350.2 & 0.0001 \\
\hline & IL-1B-31/1RN & 0.439 & 0.034 & 0.494 & 0.019 & & 0.013 & 0.08 & 7.016 & 0.0714 \\
\hline & IL-1B-511/1RN & 0.491 & 0.019 & 0.442 & 0.034 & 0.014 & & 0.75 & 6.985 & 0.0724 \\
\hline \multicolumn{11}{|c|}{ Colorectal carcinoma } \\
\hline & IL-1B-31/1B-511 & 0.007 & 0.515 & 0.471 & 0.007 & & & -0.97 & 128.1 & 0.0001 \\
\hline & IL-1B-31/1RN & 0.407 & 0.064 & 0.505 & 0.017 & 0.006 & 0.001 & 0.62 & 4.537 & 0.0336 \\
\hline & IL-1B-511/1RN & 0.504 & 0.017 & 0.407 & 0.064 & 0.001 & 0.007 & 0.50 & 6.783 & 0.0636 \\
\hline
\end{tabular}

${ }^{\mathrm{a}} \mathrm{C}$ is denoted by allele 1 and $\mathrm{T}$ is denoted by allele 2 . 
Table III. Comparison of IL-1B-31 genotype frequencies between controls and patients with gastrointestinal cancers.

\begin{tabular}{|c|c|c|c|c|c|c|c|c|c|c|c|c|c|}
\hline & \multirow[b]{2}{*}{$\begin{array}{c}\text { Control } \\
(\%)\end{array}$} & \multicolumn{12}{|c|}{ Genotype } \\
\hline & & $\begin{array}{l}\mathrm{EC} \\
(\%)\end{array}$ & $\begin{array}{c}\text { OR } \\
(95 \% \mathrm{CI})\end{array}$ & $\mathrm{P}$ & $\begin{array}{l}\mathrm{GC} \\
(\%)\end{array}$ & $\begin{array}{c}\text { OR } \\
(95 \% \mathrm{CI})\end{array}$ & $\mathrm{P}$ & $\begin{array}{l}\mathrm{CC} \\
(\%)\end{array}$ & $\begin{array}{c}\text { OR } \\
(95 \% \mathrm{CI})\end{array}$ & $\mathrm{P}$ & $\begin{array}{l}\mathrm{UC} \\
(\%)\end{array}$ & $\begin{array}{c}\text { OR } \\
(95 \% \mathrm{CI})\end{array}$ & $\mathrm{P}$ \\
\hline No. & 136 & 75 & & & 186 & & & 69 & & & 18 & & \\
\hline $\mathrm{C} / \mathrm{C}$ & $31(23)$ & $20(27)$ & 1.0 & & $45(24)$ & 1.0 & & 20 (29) & 1.0 & & $4(22)$ & 1.0 & \\
\hline $\mathrm{C} / \mathrm{T}$ & $80(59)$ & $44(59)$ & $\begin{array}{c}0.85 \\
(0.4-1.7)\end{array}$ & 0.641 & $86(46)$ & $\begin{array}{c}0.74 \\
(0.4-1.3)\end{array}$ & 0.283 & $26(38)$ & $\begin{array}{c}0.50 \\
(0.2-1.0)\end{array}$ & 0.058 & $11(61)$ & $\begin{array}{c}1.07 \\
(0.3-3.6)\end{array}$ & 0.919 \\
\hline $\mathrm{T} / \mathrm{T}$ & 25 (18) & $11(14)$ & $\begin{array}{c}0.68 \\
(0.3-1.7)\end{array}$ & 0.406 & $55(30)$ & $\begin{array}{c}1.52 \\
(0.8-2.9)\end{array}$ & 0.214 & $23(33)$ & $\begin{array}{c}1.43 \\
(0.6-3.1)\end{array}$ & 0.383 & $3(17)$ & $\begin{array}{c}0.93 \\
(0.2-4.5)\end{array}$ & 0.929 \\
\hline $\mathrm{T}$ carriers & 105 (77) & $55(73)$ & $\begin{array}{c}0.81 \\
(0.4-1.5)\end{array}$ & 0.529 & $141(76)$ & $\begin{array}{c}0.93 \\
(0.5-1.6)\end{array}$ & 0.770 & $49(71)$ & $\begin{array}{c}0.72 \\
(0.4-1.4)\end{array}$ & 0.332 & $14(78)$ & $\begin{array}{c}1.03 \\
(0.3-3.4)\end{array}$ & 0.957 \\
\hline
\end{tabular}

No., number of patients; OR, odds ratio; 95\% CI, 95\% confidence interval; EC, esophageal carcinoma; GC, gastric carcinoma; CC, colon carcinoma; T carriers, both IL-1B-31T homozygotes and IL-1B-31 heterozygotes; UC, ulcerative colitis.

Table IV. Comparison of IL-1B-511 genotype frequencies between controls and patients with gastrointestinal cancers.

\begin{tabular}{|c|c|c|c|c|c|c|c|c|c|c|c|c|c|}
\hline & \multirow[b]{2}{*}{$\begin{array}{c}\text { Control } \\
(\%)\end{array}$} & \multicolumn{12}{|c|}{ Genotype } \\
\hline & & $\begin{array}{l}\mathrm{EC} \\
(\%)\end{array}$ & $\begin{array}{c}\text { OR } \\
(95 \% \mathrm{CI})\end{array}$ & $\mathrm{P}$ & $\begin{array}{l}\text { GC } \\
(\%)\end{array}$ & $\begin{array}{c}\text { OR } \\
(95 \% \mathrm{CI})\end{array}$ & $\mathrm{P}$ & $\begin{array}{l}\mathrm{CC} \\
(\%)\end{array}$ & $\begin{array}{c}\text { OR } \\
(95 \% \mathrm{CI})\end{array}$ & $\mathrm{P}$ & $\begin{array}{l}\mathrm{UC} \\
(\%)\end{array}$ & $\begin{array}{c}\text { OR } \\
(95 \% \mathrm{CI})\end{array}$ & $\mathrm{P}$ \\
\hline No. & 136 & 75 & & & 186 & & & 69 & & & 18 & & \\
\hline $\mathrm{C} / \mathrm{C}$ & $24(18)$ & $13(17)$ & 1.0 & & $54(29)$ & 1.0 & & $23(33)$ & 1.0 & & $3(17)$ & 1.0 & \\
\hline $\mathrm{C} / \mathrm{T}$ & 80 (59) & 44 (59) & $\begin{array}{c}1.02 \\
(0.5-2.2)\end{array}$ & 0.969 & 87 (47) & $\begin{array}{c}0.48 \\
(0.3-0.9)\end{array}$ & 0.015 & $26(38)$ & $\begin{array}{c}0.34 \\
(0.2-0.7)\end{array}$ & 0.003 & $11(61)$ & $\begin{array}{c}1.10 \\
(0.3-4.3)\end{array}$ & 0.890 \\
\hline $\mathrm{T} / \mathrm{T}$ & $32(23)$ & $18(24)$ & $\begin{array}{c}1.04 \\
(0.5-2.5)\end{array}$ & 0.934 & 45 (24) & $\begin{array}{c}0.63 \\
(0.3-1.2)\end{array}$ & 0.162 & $20(29)$ & $\begin{array}{c}0.65 \\
(0.3-1.5)\end{array}$ & 0.293 & $4(22)$ & 1.0 & 1.00 \\
\hline $\mathrm{T}$ carriers & $112(82)$ & $62(83)$ & $\begin{array}{c}1.02 \\
(0.5-2.1)\end{array}$ & 0.954 & $132(71)$ & $\begin{array}{c}0.52 \\
(0.3-0.9)\end{array}$ & 0.019 & $46(67)$ & $\begin{array}{c}0.45 \\
(0.2-0.9)\end{array}$ & 0.012 & $15(83)$ & $\begin{array}{c}1.07 \\
(0.3-3.9)\end{array}$ & 0.918 \\
\hline
\end{tabular}

No., number of patients; OR, odds ratio; 95\% CI, 95\% confidence interval; EC, esophageal carcinoma; GC, gastric carcinoma; CC, colon carcinoma; T carriers, both IL-1B-511T homozygotes and IL-1B-511 heterozygotes; UC, ulcerative colitis.

$I L-1 B-511 C / T$. There was no significant difference in genotype frequency between patients with esophageal carcinoma and control subjects $\left(\chi^{2}=0.007, \mathrm{p}=0.996\right.$, Table IV). Genotype frequencies in patients with esophageal carcinoma were similar to control subjects and genotypic specific risks were not high. IL-1B-511C/T genotypes were not significantly different between patients with esophageal carcinoma and control subjects.

A significant difference in genotype frequency was seen between patients with gastric carcinoma and control subjects $\left(\chi^{2}=6.417, p=0.040\right)$. The risk of gastric carcinoma was significantly low in IL-1B-511 heterozygotes (OR, 0.48; 95\% CI, $0.3-0.9 ; \mathrm{p}=0.015$ ), and in IL-1B-511 T carriers (both IL-1B-
$511 \mathrm{~T}$ homozygotes and IL-1B-511 heterozygotes, OR, 0.52; 95\% CI, 0.3-0.9; $\mathrm{p}=0.019$ ).

A significant difference in genotype frequency was also present between patients with colorectal carcinoma and control subjects $\left(\chi^{2}=9.407, p=0.009\right)$. The risk of colorectal carcinoma was significantly low in IL-1B-511 heterozygotes (OR, 0.34; 95\% CI, 0.2-0.7; $\mathrm{p}=0.003)$, and in IL-1B-511 T carriers (OR, $0.45 ; 95 \% \mathrm{CI}, 0.2-0.9 ; \mathrm{p}=0.012)$. Genotype frequencies in patients with UC were similar to control subjects $\left(\chi^{2}=0.034\right.$, $\mathrm{p}=0.983$ ) and genotypic specific risks were not high (Table IV).

$I L-1 R N$ VNTR. As shown in Table $\mathrm{V}$, there was no significant difference in genotype frequency between control subjects 
Table V. IL-1RN VNTR genotypic frequencies in controls and patients with gastrointestinal cancers.

\section{Patients with}

Control Esophageal Gastric Colon Ulcerative subjects carcinoma carcinoma carcinoma colitis (\%) (\%)

(\%)

$(\%)$

$(\%)$

\begin{tabular}{|c|c|c|c|c|c|}
\hline No. & 136 & 75 & 186 & 69 & 18 \\
\hline $1 / 1$ & $126(93)$ & 69 (92) & $164(88)$ & $60(87)$ & $16(98)$ \\
\hline $1 / 2$ & 7 (5) & 3 (4) & $14 \quad(7)$ & 7 (11) & $2(12)$ \\
\hline $1 / 3$ & 2 (1) & 2 (3) & $3 \quad(2)$ & 1 (1) & 0 \\
\hline $1 / 4$ & 0 & 0 & 2 (1) & 0 & 0 \\
\hline $2 / 2$ & 1 (1) & 1 (1) & $3 \quad(2)$ & 1 (1) & 0 \\
\hline
\end{tabular}

No., number of patients.

and patients with esophageal carcinoma $\left(\chi^{2}=0.684, \mathrm{p}=0.953\right.$, Table V), gastric carcinoma $\left(\chi^{2}=2.817, \mathrm{p}=0.589\right)$, colorectal carcinoma $\left(\chi^{2}=2.077, \mathrm{p}=0.722\right)$, and $\mathrm{UC}\left(\chi^{2}=0.408, \mathrm{p}=0.982\right)$. After reclassifying the alleles into long and short, there was no significant difference in genotype frequency between control subjects and patients with esophageal, gastric, colorectal carcinoma, and UC (Table VI). There were no significant associations between IL-1RN genotype and the risk of development of these malignancies (Table VI).

Daily consumption of alcohol and/or cigarettes. As shown in Table I, the frequency of alcohol consumption differed significantly between the esophageal carcinoma group (64 of $75 ; 85 \%)$ and the control group $(\mathrm{p}<0.0001)$. However, the frequency of alcohol consumption in the gastric carcinoma group (69 of 186; 37\%) and the colorectal carcinoma group
(30 of $69 ; 43 \%$ ) did not differ significantly from that in the control group $(\mathrm{p}=0.5692, \mathrm{p}=0.7050)$. The frequency of daily cigarette smoking in esophageal carcinoma group (64 of 75; $85 \%)$ differed significantly from that in the control group $(p<0.0001)$. In contrast, the frequency of cigarette smoking in the gastric carcinoma group (72 of $186 ; 39 \%)$ and the colorectal carcinoma group (27 of $69 ; 39 \%$ ) did not differ significantly from that in the control group $(\mathrm{p}=0.3033$, $\mathrm{p}=0.3580$ ). Daily amount of alcohol intake (63 g/day) and a total amount of alcohol intake $(715 \mathrm{~kg})$ in patients with esophageal carcinoma differed significantly from those (15 $\mathrm{g} /$ day, $160 \mathrm{~kg})$ in control subjects $(\mathrm{p}<0.0001)$. In contrast, daily amount of alcohol intake (g/day) and a total amount of alcohol intake $(\mathrm{kg})$ in patients with gastric carcinoma (17 g/day, $230 \mathrm{~kg} /$ total) or colorectal carcinoma (17 g/day, 221 $\mathrm{kg} /$ total) did not differ significantly from control subjects (gastric carcinoma: $\mathrm{p}=0.6530, \mathrm{p}=0.2104$; colorectal carcinoma: $\mathrm{p}=0.7077, \mathrm{p}=0.3779$ ). Daily amount of cigarette smoking (20 pieces/day) and Brinkman index (B.I., 756) in patients with esophageal carcinoma differed significantly from those (6 pieces/day; B.I., 154) in control subjects $(\mathrm{p}<0.0001)$. In contrast, daily amount of cigarette smoking (pieces/day) and Brinkman index (B.I.) in patients with gastric carcinoma (9 pieces/day; B.I., 286) or colorectal carcinoma (7 pieces/day; B.I., 259) did not differ significantly from those in control subjects (gastric carcinoma: $\mathrm{p}=0.0538$, $\mathrm{p}=0.3181$; colorectal carcinoma: $\mathrm{p}=0.3010, \mathrm{p}=0.1229$ ).

Degree of inflammation and atrophy in the stomach. Degree of inflammation and atrophy was estimated in all subjects according to Sydney system. The mean scores of inflammation in the corpus of the stomach in patients with esophageal carcinoma, gastric carcinoma, colorectal carcinoma and control subjects were 1.8, 2.5, 2.3 and 1.9, respectively. The mean score of atrophy in the corpus body of the stomach in patients with esophageal carcinoma, gastric carcinoma, colorectal carcinoma and control subjects were $1.8,2.6,2.3$ and 2.0 , respectively. The mean scores of inflammation and atrophy

Table VI. Comparison of IL-1RN VNTR genotypic frequencies in controls and patients with gastrointestinal carcinoma and UC.

\begin{tabular}{|c|c|c|c|c|c|c|c|c|c|c|c|c|c|}
\hline & \multirow[b]{2}{*}{$\begin{array}{c}\text { Control } \\
(\%)\end{array}$} & \multicolumn{12}{|c|}{ Genotype } \\
\hline & & $\begin{array}{l}\mathrm{EC} \\
(\%)\end{array}$ & $\begin{array}{c}\text { OR } \\
(95 \% \mathrm{CI})\end{array}$ & $\mathrm{P}$ & $\begin{array}{l}\text { GC } \\
(\%)\end{array}$ & $\begin{array}{c}\text { OR } \\
(95 \% \mathrm{CI})\end{array}$ & $\mathrm{P}$ & $\begin{array}{l}\mathrm{CC} \\
(\%)\end{array}$ & $\begin{array}{c}\text { OR } \\
(95 \% \mathrm{CI})\end{array}$ & $\mathrm{P}$ & $\begin{array}{l}\mathrm{UC} \\
(\%)\end{array}$ & $\begin{array}{c}\text { OR } \\
(95 \% \mathrm{CI})\end{array}$ & $\mathrm{P}$ \\
\hline No. & 136 & 75 & & & 186 & & & 69 & & & 18 & & \\
\hline $\mathrm{L} / \mathrm{L}$ & $128(94)$ & $71(95)$ & 1.0 & & $169(91)$ & 1.0 & & $61(88)$ & 1.0 & & $16(89)$ & 1.0 & \\
\hline $\mathrm{L} / 2$ & 7 (5) & 3 (4) & $\begin{array}{c}0.71 \\
(0.2-3.1)\end{array}$ & 0.714 & $14 \quad(8)$ & $\begin{array}{c}1.51 \\
(0.6-3.9)\end{array}$ & 0.381 & $7(10)$ & $\begin{array}{c}2.10 \\
(0.7-6.1)\end{array}$ & 0.175 & $2(11)$ & $\begin{array}{c}1.08 \\
(0.1-9.3)\end{array}$ & 0.890 \\
\hline 2.2 & 1 (1) & 1 (1) & $\begin{array}{c}1.80 \\
(0.1-28)\end{array}$ & 0.674 & 3 (1) & $\begin{array}{c}2.27 \\
(0.2-20)\end{array}$ & 0.468 & 1 (2) & $\begin{array}{c}2.10 \\
(0.1-32)\end{array}$ & 0.594 & 0 & & \\
\hline
\end{tabular}

No., number of patients; OR, odds ratio; 95\% CI, 95\% confidence interval; EC, esophageal carcinoma; GC, gastric carcinoma; CC, colon carcinoma; UC, ulcerative colitis; L, the long allele (alleles 1, 3, 4 and 5). 
in patients with esophageal carcinoma, gastric carcinoma, and colorectal carcinoma did not differ significantly from those in control subjects.

\section{Discussion}

IL-1 is a multifunctional cytokine with high inflammatory activity. It has three members, IL- $1 \alpha, \mathrm{IL}-1 \beta$ and IL-1Ra, and there are two types of receptors; a membrane bound and soluble form. For IL-1B, three polymorphisms, C-511T, C-31T and $\mathrm{C}+3954 \mathrm{~T}$, have been reported (16). A near-complete linkage disequilibrium between polymorphisms at -31 and -511 was found for the participants. In the present study, the corresponding values in Japanese were 0.000 for C-C combination, 0.553 for C-T, 0.429 for T-C, and 0.018 for T$\mathrm{T}$ among the controls. El-Omar et al corrected their results (24), and they confirmed the more common (IL-1B-31T/IL$1 \mathrm{~B}-511 \mathrm{C}$ ) and less common (IL-1B-31C/IL-1B-511T) haplotypes. However, our data showed that $\mathrm{C}-\mathrm{T}$ type is common in Japanese subjects. It is likely that the difference in frequencies of IL-1B polymorphisms is due to difference of ethnic background between Caucasians and Japanese. Furthermore, the histologic characteristics of control subjects were estimated according to the criteria of Updated Sydney system. Since the mean scores of inflammation and atrophy in the corpus of controls tended to be low rather than those of patients with gastric carcinoma, almost all of controls did not have histologically precancerous lesions. Furuta et al reported that IL-1B-31T/IL-1B-511C was predominant in gastritisonly patients and $H$. pylori-negative control subjects (25). In contrast, other studies in Japanese populations reported IL1B-31C/IL-1B-511T was dominant in $H$. pylori-negative control subjects $(26,27)$. These results were similar to those in our study. We do not believe that the difference of IL-1B gene polymorphisms regulates infection of H. pylori, although the difference of IL-1B gene polymorphisms can regulate the degree of atrophy in the corpus. Thus, the allele identities in our study were not reversed.

Recent studies have demonstrated that IL- $1 \beta$ is an important proinflammatory cytokine highly expressed in the gastric mucosa of $H$. pylori-positive hosts; who are also known to have low gastric acid secretion $(11,16)$. El-Omar et al examined the association of particular genotypes with low acid state in Scottish and Polish gastric carcinoma patients and controls (16). They suggested that individuals with the $-31 \mathrm{~T} / \mathrm{T}$ or $\mathrm{C} / \mathrm{T}$ genotypes overexpressed gastric IL-1ß in response to inflammation and low gastric $\mathrm{pH}$. This hypothetical scheme is suitable for the precancer-cancer sequence of the gastric carcinogenesis (16). Indeed, the $\mathrm{pH}$ of gastric juice depends on the IL-1B-511 polymorphism genotype in Japanese gastric carcinoma patients. The $\mathrm{pH}$ of gastric juice is significantly higher in the patients with the T/T genotype than in those with either the $\mathrm{C} / \mathrm{T}$ or $\mathrm{C} / \mathrm{C}$ genotype (26) but the most recent study revealed that the $-31 \mathrm{C}$ to $\mathrm{T}$ base transition was inverted, in association with the $-511 \mathrm{~T}$ to $\mathrm{C}$ base transition; this means $-31 \mathrm{C}$ equals to $-511 \mathrm{~T}$, similar to the $-511 \mathrm{~T}$ to $\mathrm{C}$ base transition in Japanese (27).

In the present study, we investigated the association between the IL-1B $-31 \mathrm{C} / \mathrm{T},-511 \mathrm{C} / \mathrm{T}$ or IL-1RN VNTR polymorphisms and the risk of esophageal, gastric and colorectal carcinomas in Japanese patients with $H$. pylori infection. El-Omar et al reported that carriers of IL-1B-31T and IL-1RN2 homozygotes (IL-1RN*2) were at higher risk for development of gastric carcinoma at ORs of 1.9 (95\% CI, 1.5-2.6) and 3.7 (95\% CI, 2.4-5.7), respectively (16). In the present study, the frequencies of IL-1B-31 and -511 genotype in patients with esophageal carcinoma were similar to the control. Furthermore, the risk of esophageal carcinoma was not related to IL-1B and IL-1RN VNTR polymorphisms. In Japan, $95 \%$ of esophageal carcinomas are of the squamous cell type (28). The risk factors of esophageal carcinoma include daily consumption of alcohol and/or cigarette smoking (29). In our study, the frequency of daily consumption of alcohol or cigarettes in esophageal carcinoma group differed significantly from that in the control group. However, such frequency in gastric carcinoma group or in colorectal carcinoma group did not differ significantly from that in control group. Daily consumption of alcohol and/or cigarettes is associated with the risk of esophageal carcinoma. Irritation by daily consumption of alcohol and/or cigarettes may cause carcinoma of the esophagus. We believe that host genetic factors affecting cytokines such as IL-1ß are unlikely to be associated with risk of esophageal carcinoma in Japanese population.

In contrast, $H$. pylori infection increases the risk of gastric carcinoma both in Japanese and Europeans $(6,30)$. Gastritis involving the acid-secreting corpus region leads to hypochlorhydria and progressive gastric atrophy, which increase the risk of gastric carcinoma $(8,31)$. In the present study, although $H$. pylori infection was found in both patients with gastric carcinoma and control subjects, a significant difference in IL-1B polymorphisms was noted between the two groups. Unlike esophageal carcinoma, we believe that genetic factors affecting cytokines such as IL-1ß are likely to be associated with the risk of gastric carcinoma in Japanese population. In this regard, Takashima et al (32) reported that gastric acid secretion was low and serum gastrin levels were high in Mongolian gerbils infected with $H$. pylori. They concluded that this change in gastric acid secretion appears to be mediated by IL-1ß induced by $H$. pylori infection. Based on these studies, we hypothesize that differences in IL-1B polymorphisms in hosts infected with $H$. pylori may be associated with differences in gastric acid secretion caused by IL-1ß, consequently leading to progressive gastritis and increasing the risk for gastric carcinogenesis. However, the frequencies of IL-1B polymorphisms in our study were quite different from those in the study by El-Omar et al (16). It is likely that the difference in frequencies of IL-1B polymorphisms is due to differences in ethnic background. Further studies are necessary to investigate the relationships between gastric carcinoma and IL-1B polymorphisms.

Our results showed significant differences in IL-1B polymorphisms between patients with colorectal carcinoma and control subjects. We believe that genetic factors affecting cytokines such as IL-1ß could be associated with increased risk of colorectal carcinoma in Japanese population. The IL-1 gene family has been extensively studied in patients with inflammatory bowel diseases (IBD) (33-39), including the relationship between gene polymorphisms and disease susceptibility or disease progression. Mansfield et al 
investivated the relationship between UC and IL-1RN polymorphism, and IL- $1 \mathrm{RN}^{*} 2$ was initially reported to be associated with increased risk of UC (33). In the present study, the frequencies of IL-1B-31, -511 and IL-1RN genotype in patients with UC were similar to control subjects, and the risk of UC was not related to IL-1B and IL1RN VNTR polymorphisms. Conversely, IL-1B-511 heterozygotes and $\mathrm{T}$ carriers contributed to the low risk of colorectal carcinoma despite sporadic cases. To our knowledge, there is no report of relationships between IL-1 polymorphisms and risk of colorectal carcinoma. In contrast, IL-1B-511 heterozygotes and T carriers also showed low risk of gastric carcinoma in our study. IL-1ß is a potent inhibitor of gastric acid secretion $(40,41)$, and association of IL-1B polymorphism with gastric acid secretion is supported (16). Thus, gastric acid secretion may affect the $\mathrm{pH}$ of the intestinal tract. If $\mathrm{pH}$ in the large intestine is regulated by IL-1B polymorphisms, direct mucosal injury or abnormality of intestinal bacterial flora may depend on $\mathrm{pH}$. We hypothesize that $\mathrm{pH}$ in the intestinal tract could be associated with the risk of carciongenesis of the large intestine. Furthermore, polymorphism combination of IL-1B-31/IL-1B-511 and IL-1B-31/ IL-1RN would be associated with the risk of colorectal carcinoma development.

In summary, our results suggest that IL-1B polymorphisms are associated with low risk of gastric and colorectal carcinogenesis. The putative underlying mechanism involves amplification of the host inflammatory response to $H$. pylori infection. While pro-inflammatory genotypes may be advantageous for the host response against certain bacterial infections in the large intestine, IL-1ß overproduction associated with such infections may damage the colorectal mucosa, eventually leading to carcinoma development. In contrast, host genetic factors involving IL-1B are unlikely to be associated with increased risk of esophageal carcinoma in Japanese population.

\section{Acknowledgements}

This study was supported in part by the Grant-in-Aid for Cancer Research (14-3) from the Ministry of Health, Labor and Welfare, and was also supported in part by a Showa University Grant-in-Aid for Innovative Collaborative Research Projects and a Special Research Grant-in-Aid for Development of Characteristic Education from the Japanese Ministry of Education, Culture, Sports, Science and Technology of Japan.

\section{References}

1. Parkin DM, Pisani P and Ferlay J: Estimates of the worldwide incidence of 25 major cancers in 1990. Int J Cancer 80: 827-841, 1999.

2. Banatvala N, Mayo K, Megraud F, et al: The cohort effect and Helicobacter pylori. J Infect Dis 168: 219-221, 1993.

3. Goodman KJ and Correa P: The transmission of Helicobacter pylori. A critical review of the evidence. Int J Epidemiol 24: 875-887, 1995.

4. Cave DR: How is Helicobacter pylori transmitted? Gastroenterology 113: S9-S14, 1997.

5. IARC Working Group on the Evaluation of Carcinogenic Risks to Humans: Infection with Helicobacter pylori: schistosomes, liver flukes and Helicobacter pylori. IARC monographs on the evaluation of carcinogenic risks to humans. IARC 61: 177-240, 1994.
6. Nomura A, Stemmermann GN, Chyou PH, et al: Helicobacter pylori infection and gastric carcinoma among Japanese Americans in Hawaii. N Engl J Med 325: 1132-1136, 1991.

7. Parsonnet J, Friedman GD, Vandersteen DP, et al: Helicobacter pylori infection and the risk of gastric carcinoma. N Engl J Med 325: 1127-1131, 1991.

8. Correa P: Human gastric carcinogenesis: a multistep and multifactorial process. First American Cancer Society Award Lecture on Cancer Epidemiology and Prevention. Cancer Res 52: 6735-6740, 1992.

9. Sato S, Fukuyama S, Suzuki T, et al: The relationship between gastric cancer mortality and salted food intake in several places in Japan. Bull Inst Public Health 8: 187-198, 1959.

10. Tsugane S, Tei Y, Takahashi T, et al: Salty food intake and risk of Helicobacter pylori infection. Jpn J Cancer Res 85: 474-478, 1994.

11. Wolfe MM and Nompleggi DJ: Cytokine inhibition of gastric acid secretion - a little goes a long way. Gastroenterology 102: 2177-2178, 1992 .

12. Dinarello CA: Biologic basis for interleukin-1 in disease. Blood 87: 2095-2147, 1996.

13. Noach LA, Bosma NB, Jansen J, et al: Mucosal tumor necrosis factor-alpha, interleukin-1 beta, and interleukin- 8 production in patients with Helicobacter pylori infection. Scand J Gastroentrol 29: 425-429, 1994.

14. Basso D, Scrigner M, Toma A, et al: Helicobacter pylori infection enhances mucosal interleukin-1 beta, interleukin-6, and the soluble receptor of interleukin-2. Int J Clin Lab Res 26: 207-210, 1996.

15. Arend WP, Malyak M, Guthridge CJ, et al: Interleukin-1 receptor antagonist: role in biology. Annu Rev Immunol 16: 27-55, 1998.

16. El-Omar EM, Carrington M, Chow WH, et al: Interleukin-1 polymorphisms associated with increased risk of gastric cancer. Nature 404: 398-402, 2000.

17. Santtila S, Savinainen K and Hurme M: Presence of the IL-1RA allele 2 (IL1RN2) is associated with enhanced IL-1 beta production in vitro. Scand J Immunol 47: 195-198, 1998.

18. Mowat C, Murray L, Hilditch TE, et al: Comparison of helisal rapid blood test and $14 \mathrm{C}$-urea breath test in determining Helicobacter pylori status and predicting ulcer disease in dyspeptic patients. Am J Gastroenterol 93: 20-25, 1998.

19. Dixon MF, Genta RM, Yardley JH, et al: Classification and grading of gastritis. The updated Sydney System. International Workshop on the Histopathology of Gastritis, Houston, TX, 1994. Am J Surg Pathol 20: 1161-1181, 1996.

20. El-Omar EM, Oien K, El-Nujumi A, et al: Helicobacter pylori infection and chronic gastric acid hyposecresion. Gastroenterology 113: 15-24, 1997.

21. Makino R, Kaneko K, Kurahashi T, et al: Detection of the P53 gene with high sensitivity by fluorescence-based PCR-SSCP analysis using low-pH buffer and automated DNA sequencer in large number of DNA samples. Mutat Res 452: 83-90, 2000.

22. Kukita Y, Tahira T, Sommer SS, et al: SSCP analysis of long DNA fragments in low pH gel. Hum Mutat 10: 400-407, 1997.

23. Tarlow JK, Blakemore AL, Lennard A, et al: Polymorphism in human IL-1 receptor antagonist gene intron 2 is caused by variable numbers of an 86-bp tandem repeat. Hum Genet 91: 403-404, 1993.

24. El-Omar EM, Carrington M, Chow WH, et al: The role of interleukin-1 polymorphisms in the pathogenesis of gastric cancer. Nature 412: 99, 2001.

25. Furuta T, El-Omar EM, Fang W, et al: Interleukin 1 polymorphisms increase risk of hypochlorhydria and atrophic gastritis and reduce risk of duodenal ulcer recurrence in Japan. Gastroenterology 123: 92-105, 2002

26. Kato S, Onda M, Yamada S, et al: Association of the interleukin-1beta genetic polymorphism and gastric cancer risk in Japanese. J Gastroenterol 36: 696-699, 2001.

27. Hamajima N, Matsuo K, Saito T, et al: Interleukin 1 polymorphisms, lifestyle factors, and Helicobacter pylori infection. Jpn J Cancer Res 92: 383-389, 2001.

28. Japanese Research Society for Esophageal Diseases: The Report of Treatment Results of Esophageal Carcinoma in Japan. National Cancer Centre, Tokyo, 1997.

29. Jacob JH, Riviere A, Mandard AM, et al: Prevalence survey of precancerous lesions of the oesophagus in a high-risk population for oesophageal cancer in France. Eur J Cancer Prev 2: 53-59, 1993. 
30. The Eurogast Study Group: An international association between Helicobacter pylori infection and gastric cancer. Lancet 341 : 1359-1362, 1993.

31. Sipponen P: Gastric cancer - a long-term consequence of Helicobacter pylori infection? Scand J Gastroenterol 201: 24-27, 1994.

32. Takashima M, Furuta T, Hanai H, et al: Effects of Helicobacter pylori infection on gastric acid secretion and serum gastrin levels in Mongolian gerbils. Gut 48: 765-773, 2001.

33. Mansfield JC, Holden H, Tarlow JK, et al: Novel genetic association between ulcerative colitis and the anti-inflammatory cytokine interleukin-1 receptor antagonist. Gastroenterology 106: 637-642, 1994.

34. Tountas NA, Casini-Raggi V, Yang H, et al: Functional and ethnic association of allele 2 of the interleukin- 1 receptor antagonist gene in ulcerative colitis. Gastroenterology 117 : 806-813, 1999.

35. Bioque G, Bouma G, Crusius JB, et al: Evidence for genetic heterogeneity in IBD: the interleukin-1 receptor antagonist in the predisposition to suffer from ulcerative colitis. Eur J Gastroenterol Hepatol 8: 105-110, 1996.
36. Louis E, Satangi J, Roussomoustakaki M, et al: Cytokine gene polymorphisms in inflammatory bowel disease. Gut 39: 705-710, 1996.

37. Hacker UT, Gomolka M, Keller E, et al: Lack of association between an interleukin-1 receptor antagonist gene polymorphism and ulcerative colitis. Gut 40: 623-627, 1997.

38. Roussomoustakaki M, Satsangi J, Welsh K, et al: Genetic markers may predict disease behavior in patients with ulcerative colitis. Gastroenterology 112: 1845-1853, 1997.

39. Stokkers PC, van Aken BE, Basoski N, et al: Five genetic markers in the interleukin 1 family in relation to inflammatory bowel disease. Gut 43: 33-39, 1998.

40. Brand AH and Perrimon N: Targeted gene expression as a means of altering cell fates and generating dominant phenotypes. Development 118: 401-415, 1993.

41. Warrick JM, Paulson HL, Gray-Board GL, et al. Expanded polyglutamine protein forms nuclear inclusions and causes neural degeneration in Drosophila. Cell 93: 939-949, 1998. 